\title{
Bactericidal Properties of Murine Intestinal Phospholipase $\mathbf{A}_{2}$
}

Sylvia S. L. Harwig, Leonie Tan, Xiao-Dan Qu, Yoon Cho, Patricia B. Eisenhauer, and Robert I. Lehrer

Department of Medicine, UCLA School of Medicine, Los Angeles, California 90024

\begin{abstract}
We purified a molecule from the murine small intestine that killed both Escherichia coli and Listeria monocytogenes, and identified it as intestinal phospholipase $\mathbf{A}_{2}$ (iPLA $)$ by $\mathbf{N H}_{2}-$ terminal sequencing and enzymatic measurements. The ability of $i P L A_{2}$ to kill. $L$. monocytogenes was greatly enhanced by $5 \mathrm{mM}$ calcium, inhibited by EGTA and abolished after reduction and alkylation, suggesting that enzymatic

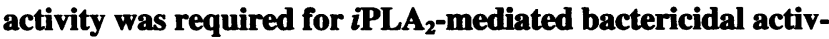
ity. A mouse-avirulent phoP mutant, S. typhimurium 7953S, was 3.5-fold more susceptible to $i P L A_{2}$ than its isogenic virulent parent, $S$. typhimurium $14028 \mathrm{~S}$ (estimated minimal bactericidal concentrations $12.7 \pm 0.5 \mu \mathrm{g} / \mathrm{ml} v s .43 .9 \pm 4.5 \mu \mathrm{g} / \mathrm{ml}$, $P<0.001$ ). Overall, these findings identify $i P L A_{2}$ as part of the antimicrobial arsenal that equips Paneth cells to protect the small intestinal crypts from microbial invasion. Because $i P L A_{2}$ is identical to Type 2 phospholipase $A_{2}$ molecules found in other sites, including spleen, platelets and inflammatory exudate cells, this enzyme may also contribute to antibacterial defenses elsewhere in the body. ( $J$. Clin. Invest. 1995. 95:603-610.) Key words: defense mechanisms - host-parasite relations - immunity, natural • intestinal mucosa $\cdot$ phospholipases A
\end{abstract}

\section{Introduction}

Despite an intermittently rich content of nutrients and the repeated entry of bacteria in food and oral secretions, the small intestine normally contains very few microorganisms (1). The host factors that prevent local microbial proliferation are uncertain, but gastric acidity, epithelial cell shedding, the mechanical effects of peristalsis, and the actions of bile salts are traditionally mentioned.

Paneth cells are specialized epithelial cells located in the basal portion of intestinal crypts, subjacent to the zone of intestinal epithelial cell division. They contain and secrete lysozyme and enteric defensins ("cryptdins") that are homologous to the antimicrobial defensins found in myeloid cells (2-8). Given the strategic location of Paneth cells, their content of antimicrobial proteins and peptides, and their phagocytic $(9,10)$ and

Address correspondence to Robert I. Lehrer, M.D., Department of Medicine, UCLA-Center for the Health Sciences, 10833 LeConte Ave., Los Angeles, CA 90024-1678. Phone: 310-825-0133; FAX: 310-206-8766.

Received for publication 24 May 1994 and in revised form 20 September 1994.

J. Clin. Invest.

(C) The American Society for Clinical Investigation, Inc. 0021-9738/95/02/0603/08 \$2.00

Volume 95, February 1995, 603-610 secretory $(11,12)$ abilities, these once enigmatic cells are likely to contribute to intestinal antimicrobial defenses.

During a recent purification of cryptdins from preparations enriched for murine Paneth cells, we noted the presence of larger polypeptides with very potent antimicrobial activity (see Fig. $1 b$ in reference 6 ). We now describe the purification of one of these molecules, and its identification as a Type 2 phospholipase $\mathrm{A}_{2}$, a known Paneth cell constituent in rats (13) and humans (14).

\section{Methods}

\section{Identification of antimicrobial Paneth cell components}

Preparation of a Paneth cell-enriched fraction from murine small intestine was described recently (6). Briefly, small intestines were excised from fasted female adult Swiss Webster mice, quadrisected, flushed with $0.9 \% \mathrm{NaCl}$ containing $1 \mathrm{mM}$ dithiothreitol, everted over thin glass pipettes, and twice incubated for $\mathbf{3 0} \mathrm{min}$ in phosphate buffered saline with $27 \mathrm{mM}$ sodium citrate, $\mathrm{pH}$ 7.4. The exfoliated cells were combined, recovered by centrifugation $\left(450 \mathrm{~g}, 10 \mathrm{~min} 4^{\circ} \mathrm{C}\right)$ resuspended in ice-cold $0.34 \mathrm{M}$ sucrose, $\mathrm{pH} 7.4$, disrupted in a Potter-Elvehjem homogenizer to $>90 \%$ cellular breakage. A post nuclear supernatant was prepared, centrifuged $(27,000 \mathrm{~g}, 20 \mathrm{~min})$ and its pellet was extracted with icecold $5 \%$ acetic acid to provide starting material for our initial studies.

This extract was chromatographed on a SynChropak GPC $100 \mathrm{col}-$ umn (Synchrom, Lafayette, IN) with $100 \mathrm{mM}$ ammonium acetate-1\% acetic acid in $10 \%$ acetonitrile. Each fraction was tested for antimicrobial activity against Listeria monocytogenes EGD by a radial diffusion assay (15), and examined by acid-urea polyacrylamide gel electrophoresis (AU-PAGE). ${ }^{1}$ Fractions of interest were further purified by reversephase high-performance liquid chromatography (RP-HPLC) on a 4.6 $\times 250 \mathrm{~mm}$ Vydac C-18 column (The Separations Group, Hesperia CA), using a linear water-acetonitrile gradient that contained $0.1 \%$ trifluoroacetic acid (TFA) and increased by $1 \%$ acetonitrile $\min ^{-1}$. Each RP-HPLC fraction was tested for antimicrobial activity, and examined by AU-PAGE and SDS-PAGE. Fractions containing enteric defensins (cryptdins) and lysozyme were identified and reserved for other studies, and other fractions with potent antimicrobial activities were selected for further purification. The protein described in this report was initially recognized by gel overlay assays (15) against $L$ monocytogenes and we provisionally identified it as a Type 2 intestinal $P_{2} A_{2}$ by performing $\mathrm{NH}_{2}$-terminal microsequencing after electro-transferring it to a PVDF membrane (16).

\section{Scaled-up purification}

To obtain larger amounts of this iPLA, $30 \mathrm{~g}$ of mouse intestinal acetone powder (catalog number I-1755; Sigma Chemical Co., St. Louis, MO) was homogenized in $300 \mathrm{ml}$ ice-cold $1 \mathrm{~N} \mathrm{HCl}$, stirred for $4 \mathrm{~h}$ in the cold, and centrifuged at $27,000 \mathrm{~g}$ for $20 \mathrm{~min}$ at $4^{\circ} \mathrm{C}$. The insoluble residue was re-extracted as above, and the combined supernatants were ultrafiltered sequentially through YM 30 and YM 5 membranes (Ami-

1. Abbreviations used in this paper: AU-PAGE, acid-urea PAGE iPLA $A_{2}$, intestinal phospholipase $A_{2}$; eMBC, estimated minimal bactericidal concentration; $\mathrm{PLA}_{2}$, phospholipase $\mathrm{A}_{2}$; PVDF, polyvinylidene difluoride; RP-HPLC, reversed phase-HPLC; TFA, trifluoroacetic acid. 

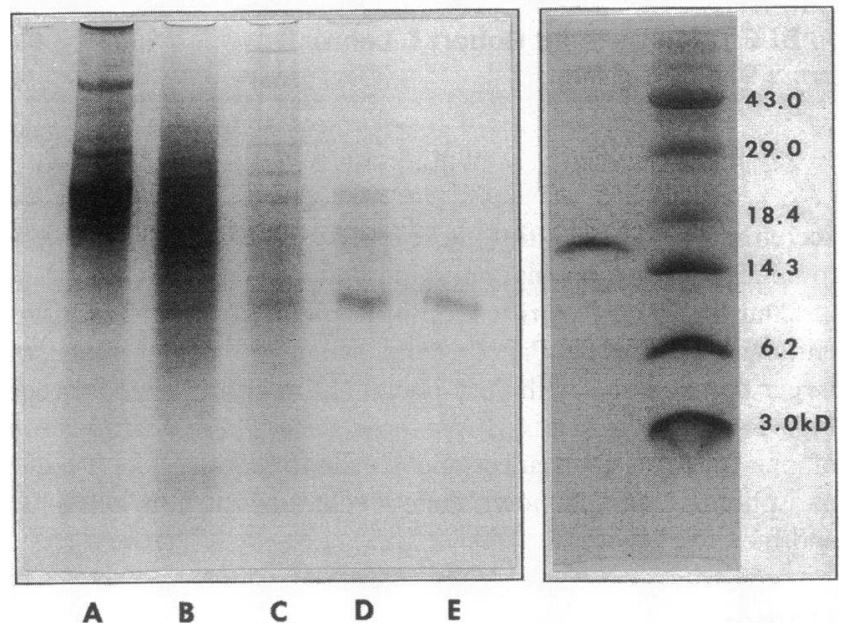

Figure 1. Purification of $i$ PLA2 from mouse intestine acetone powder. AU-PAGE gels illustrating the stages of purification. Lane $A$, crude $1 N$ $\mathrm{HCl}$ extract ( $20 \mu \mathrm{g}$ protein); lane $B$, YM30 filtrate/YM 5 retentate (20 $\mu \mathrm{g}$ protein); Lane $C$, pooled PLA $_{2}$-containing fractions after RP-HPLC (10 $\mu$ g protein); lane $D$, PLA $_{2}$-containing fractions after cation exchange HPLC ( $4 \mu \mathrm{g}$ protein); lane $E$, purified PLA $_{2}$ after continuous AU-PAGE ( $1 \mu \mathrm{g}$ protein). The inset on the right shows a silver stained Tricine SDS-PAGE of the purified material.

con, Inc., Beverly, MA). The YM 30 filtrate/YM 5 retentate was purified by RP-HPLC on a $10 \times 250 \mathrm{~mm}$ Vydac C-18 column with a linear water-acetonitrile gradient that contained $0.1 \%$ TFA. Each fraction was examined by AU-PAGE and tested for PLA $\mathrm{A}_{2}$ enzyme activity with $\left[{ }^{14} \mathrm{C}\right]$ oleic acid-labeled $E$. coli, as described below. Fractions with phospholipase activity were concentrated, dialyzed against $50 \mathrm{mM}$ phosphate buffer, $\mathrm{pH}$ 6.55, chromatographed on a PolyCat-A cation-exchange HPLC column (PolyLC, Columbia, MD), eluted with a gradient of $\mathrm{NaCl}$ and desalted by RP-HPLC. After concentration, the PLA $\mathrm{A}_{2}$ was further purified by preparative AU-PAGE (17) on a Model 491 Prep Cell (Bio-Rad Laboratories, Hercules, CA) that contained an $8 \mathrm{~cm}$ high, $12.5 \%$ acrylamide gel. Final purification was accomplished by RP-HPLC on a $4.6 \times 250 \mathrm{~mm}$ Vydac C-18 column. From $30 \mathrm{~g}$ of acetone powder, we recovered $\sim 120 \mu \mathrm{g}$ of highly purified PLA 2 plus an additional $180 \mu \mathrm{g}$ of $>95 \%$ pure PLA $_{2}$. The highly purified preparation was used for all studies reported here, unless otherwise noted.

\section{Phospholipase $A_{2}$ assays}

Bacteria. Autoclaved $\left[{ }^{14} \mathrm{C}\right.$ ] oleic acid-labeled E. coli ML-35 were prepared essentially as described by Elsbach and Weiss (18), and their specific activity was adjusted by adding autoclaved native bacteria, so that $50,000 \mathrm{cpm}$ corresponded to approximately $2.5 \times 10^{8}$ total bacteria. Samples were incubated for $15 \mathrm{~min}$ at $37^{\circ} \mathrm{C}$ with ${ }^{14} \mathrm{C}$ - E . coli $(50,000$ cpm) in $250 \mu \mathrm{l}$ of $250 \mathrm{mM}$ Tris buffer that contained $10 \mathrm{mM} \mathrm{CaCl}$ and $1 \mathrm{mg} / \mathrm{ml}$ bovine serum albumin, $\mathrm{pH} 9.5$. The reaction was stopped by adding $100 \mu \mathrm{l}$ of $2 \mathrm{~N} \mathrm{HCl}$ followed by $100 \mu \mathrm{l}$ of $20 \mathrm{mg} / \mathrm{ml}$ fatty acid-free bovine serum albumin (Sigma Chemical Co.). After $30 \mathrm{~min}$ on ice, the samples were centrifuged at $10,000 \mathrm{~g}$ for $5 \mathrm{~min}$ and the pellet was washed twice with $200 \mu \mathrm{l}$ ice cold $0.1 \%$ acetic acid. The combined supernatants, which contained released $\left[{ }^{14} \mathrm{C}\right]$ oleic acid, were analyzed by scintillation counting.

Egg yolk assay. PLA 2 activity was also measured as described by Habermann and Hardt (19). Briefly, fresh egg yolk (1 vol) and $0.85 \%$ $\mathrm{NaCl}$ ( $3 \mathrm{vol}$ ) were mixed and centrifuged at $2,000 \mathrm{rpm}$. $1 \mathrm{ml}$ of supernatant was added to $98 \mathrm{ml}$ of a $0.6 \%$ agarose solution in $50 \mathrm{mM}$ sodium acetate/barbital buffer at $50^{\circ} \mathrm{C}(\mathrm{pH} 7.5)$, followed by $1 \mathrm{ml}$ of $10 \mathrm{mM}$
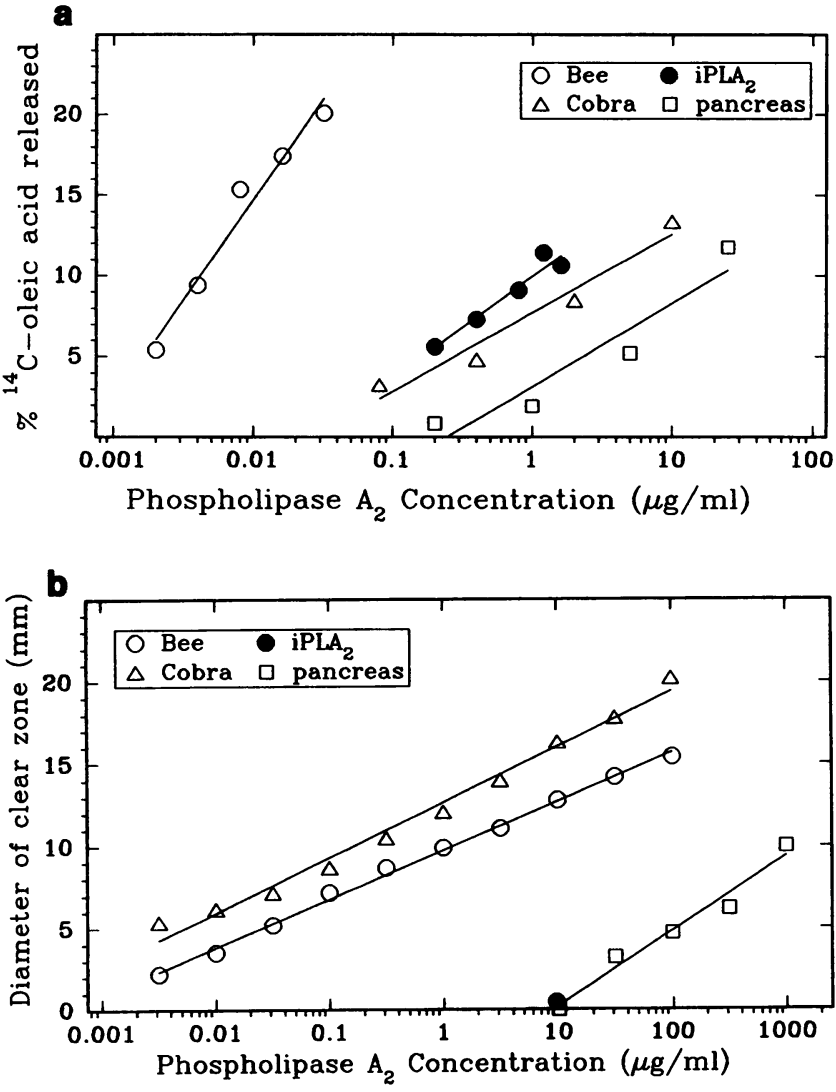

Figure 2. Enzyme activity. Purified murine PLA $_{2}$ was compared with $\mathrm{PLA}_{2} \mathrm{~s}$ obtained from cobra venom (Naja mocambique) and bovine pancreas, with autoclaved $\left[{ }^{14} \mathrm{C}\right]$ oleic acid-labeled $E$. coli $(a)$ or egg yolk $(b)$ as substrate.

$\mathrm{CaCl}_{2} .15 \mathrm{ml}$ of this mixture was poured into a petri dish and 3-mm wells were cut in the gel so that 5- $\mu$ l test samples could be accomodated. The diameters of the clear zones were measured after overnight incubation at room temperature. In addition to the murine $i \mathrm{PLA}_{2}$, we also obtained several phospholipase $A_{2}$ preparations from Sigma Chemical Co., including enzymes from bee venom, $1350 \mathrm{U} / \mathrm{mg}$ protein, bovine pancreas, $70 \mathrm{U} / \mathrm{mg}$ protein, and Naja mocambique mocambique 1,700 $\mathrm{U} / \mathrm{mg}$ protein (acidic isozyme).

\section{Antimicrobial testing}

Bacteria. E. coli ML-35 and 35p were described previously (15). Salmonella typhimurium strains 14028 and $7953 S$ were gotten from Fred Heffron of the University of Oregon Medical Center and $L$. monocytogenes, EGD was provided by Pieter Hiemstra of the University of Leiden, The Netherlands.

Methods. Gel overlay and radial diffusion assays (15) were used to identify and track the active fractions during their many cycles of purification. For radial diffusion assays, we applied $5 \mu \mathrm{l}$ samples dissolved in $0.01 \%$ acetic acid to wells in thin $(1.23 \mathrm{~mm})$ agarose underlayers that contained approximately $4 \times 10^{5}$ bacteria per ml. After $3 \mathrm{~h}$ at $37^{\circ} \mathrm{C}$, the underlayers were covered with an equally thin overlay of double-strength $(60 \mathrm{~g} / 1)$ trypticase soy agar (BBL Microbiology Systems, Cockeysville, MD) that allowed surviving bacteria to form visible microcolonies. After an $18-\mathrm{h}$ incubation at $37^{\circ} \mathrm{C}$, the diameter of the clear zones were measured and, after subtracting the diameter of the well $(3 \mathrm{~mm})$, the difference was expressed in units $(1 \mathrm{~mm}=10 \mathrm{U})$ (15). We estimated the minimal bactericidal concentrations (eMBC) by performing linear regression analyses to determine the concentration 


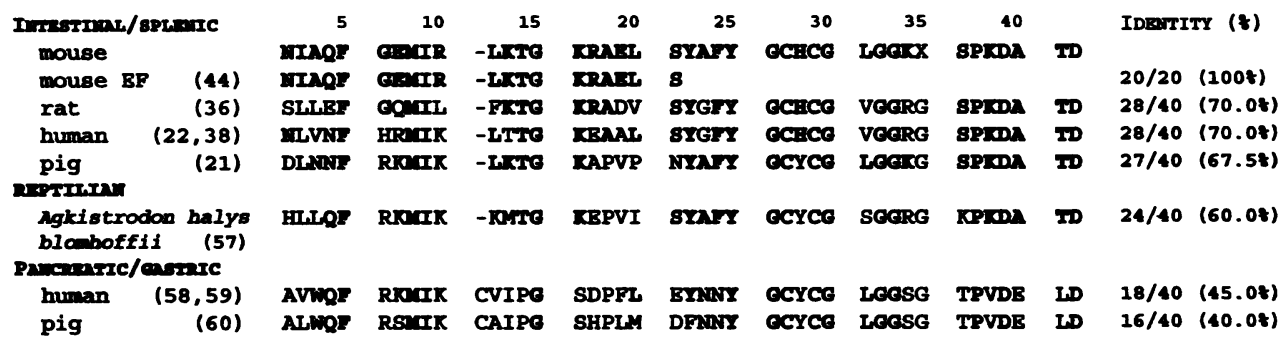

Figure 3. $\mathrm{NH}_{2}$ terminal sequences of $\mathrm{PLA}_{2}$. Amino acids are shown in standard single letter code, and are numbered according to reference 24. $X$ denotes an unidentified residue. Sources: Intestinal/splenic: mouse $i \operatorname{PLA}_{2}$ (this paper), mouse EF (43), rat (34), pig (20), human (31, 36), Reptilian: A. blomhoffii (49), Pancreatic human (50,51), pig (52), guinea pig (53). Residues identical to mouse $i \mathrm{PLA}_{2}$ are indicated in bold letters. The number and percentage of residues identical to mouse $i P^{2} A_{2}$ are shown in the right column.

of peptide corresponding to $20 \mathrm{U}$ of activity. This concentration, which we call the $\mathrm{C}_{20}$ value, was converted to $\mu \mathrm{g} / \mathrm{ml}$ by a formula, eMBC $=0.32\left(C_{20}\right)$, derived from calculations that took into account the volume of underlayer agar corresponding to a diameter of $20 \mathrm{U}[1 / 4 \pi \mathrm{h}$ $\left(d_{1}^{2}-d_{2}^{2}\right)$; where $\mathrm{h}=1.23 \mathrm{~mm}, d_{1}=5 \mathrm{~mm}$ and $d_{2}=3 \mathrm{~mm}$, the volume of peptide placed in the well $(5 \mu \mathrm{l})$, and the calculated $\mathrm{C}_{20}$. Complete absence of micro-colonies in the clear zones that surrounded the wells was confirmed by direct microscopy under a magnification of 40. Approximately $6 \times 10^{3}$ micro-colonies were present in control areas equivalent in size to $20 \mathrm{U}$.

Since this assay was performed by adding very small peptide/protein samples $(5 \mu \mathrm{l})$ to a relatively large antibiotic-free gel $(10 \mathrm{ml})$, the test items underwent considerable dilution as they diffused into the underlay. Such dilution would have allowed transiently inhibited but still viable organisms to resume growth after local concentrations of the agent had fallen below its inhibitory threshhold. Consequently, although the radial diffusion assay reflects bactericidal activity accurately, it is poorly suited for measuring bacteriostatic activity, differing in this respect from conventional agar or broth dilution antibiotic assays which measure both, because the test antibiotics are uniformly dispersed throughout the medium.

Colony count assays were performed by incubating approximately $1 \times 10^{6} \mathrm{CFU} \mathrm{ml}^{-1}$ of mid-logarithmic phase bacteria with $\mathrm{iPLA}_{2}$ at $37^{\circ} \mathrm{C}$ in $10 \mathrm{mM}$ sodium phosphate buffer that contained $0.3 \mathrm{mg} \mathrm{ml}^{-1}$ of trypticase soy broth powder (BBL Microbiology Systems). At predetermined intervals, aliquots were removed, diluted and applied to the surface of nutrient agar plates with a Model C Spiral Spreader (Spiral Systems, Cincinnati, $\mathrm{OH}$ ). Colonies were counted 24h later and converted to CFU ml-1 after correction for dilution and geometry

\section{Sequences}

Approximately $0.3 \mathrm{nmol}$ of the purified peptide was subjected to Edman sequencing on a Porton model 2090 sequencer (Beckman Instruments, Fullerton, CA).

\section{Results}

Initial identification of phospholipase $A_{2}$. We previously reported that multiple antimicrobial components were present when Paneth cell granule extracts were tested against $L$. monocytogenes EGD in gel overlay assays (See Fig. $1 b$ in reference $6)$. After the initial gel permeation chromatography and RPHPLC steps, we observed that fractions eluting at $37-38 \%$ acetonitrile consistently manifested antimicrobial activity, but did not contain cryptdins or lysozyme. After further micro-scale purification of the active component, whose apparent mass was $16 \mathrm{kD}$ by SDS-PAGE (data not shown), it was electro-transferred to a PVDF membrane. Microsequencing gave the follow- ing result: NIAQFGEMIRLKTGKRAELSYAFYG. Search of the Swiss-Prot 19 computer data base using the FASTA algorithm revealed homology to phospholipase $A_{2}$ enzymes, further described below.

Purification from intestinal acetone powders. Because preparation of granules from freshly exfoliated epithelial cells was tedious and ultimately provided only a few micrograms of purified $i P_{2 A}$, we turned to commercial mouse intestinal acetone powders to obtain material for its larger scale purification. After acid extraction, purification was accomplished with a five-step procedure consisting of: size selection by ultrafiltration, RPHPLC, cation-exchange HPLC, preparative AU-PAGE and final RP-HPLC (Fig. 1). RP-HPLC followed by cation exchangeHPLC of the YM-5 retentate yielded a substantially purified preparation with one major and 2 minor components noted on AU-PAGE. Phospholipase $A_{2}$, the major and most cationic component, was separated from the minor contaminants by preparative continuous AU-PAGE (17). Unless otherwise stated, the final $i \mathrm{PLA}_{2}$ preparations used for the experiments described herein appeared homogeneous by RP-HPLC, AU-PAGE, and SDS-PAGE analysis.

Enzyme activity. In the ${ }^{14} \mathrm{C}$-labeled $E$. coli assay (18), purified murine intestinal phospholipase $\mathrm{A}_{2}$ was about 10-fold more active than bovine pancreatic phospholipase $A_{2}$ (Fig. 2), and slightly more active than a phospholipase $\mathrm{A}_{2}$ derived from Cobra venom (Naja mocambique mocambique). As expected (20, 21 ), murine $i \mathrm{PLA}_{2}$ was inactive in the classical egg yolk assay at $10 \mu \mathrm{g} / \mathrm{ml}$, the highest concentration we tested (data not shown).

Sequence analysis. The partial, $\mathrm{NH}_{2}$-terminal amino acid sequence of purified murine intestinal phospholipase $A_{2}$ is shown in Fig. 3, which also compares it with other PLA $A_{2}$ enzymes and to murine intestinal "Enhancing Factor"' (see Discussion). The homologies and especially the absence of the cysteine residue universally present at position 11 in Type 1 PLA $_{2}$ enzymes, identifies the murine protein as a Type 2 PLA $_{2}$.

Antimicrobial activity. Purified murine $i \mathrm{PLA}_{2}$ killed $E$. coli ML-35p and $L$. monocytogenes $E G D$, as shown by the radial diffusion assays illustrated in Fig. 4, which were performed in the absence of additional calcium. On a weight basis $i \mathrm{PLA}_{2}\left(M_{\mathrm{r}}\right.$ $\approx 16 \mathrm{kD}$ ) was 3-4-fold less potent than rabbit defensin NP-1 $\left(M_{\mathrm{r}} \approx 4 \mathrm{kD}\right)$, but on a molar basis their efficacy was similar. Although $i \mathrm{PLA}_{2}$ killed both mouse-virulent wild-type $S$. typhimurium strain $14028 \mathrm{~S}$ and its avirulent phoP mutant, strain 7953S (Fig. 5 and Table I), the latter was approximately $3.5 \times$ 


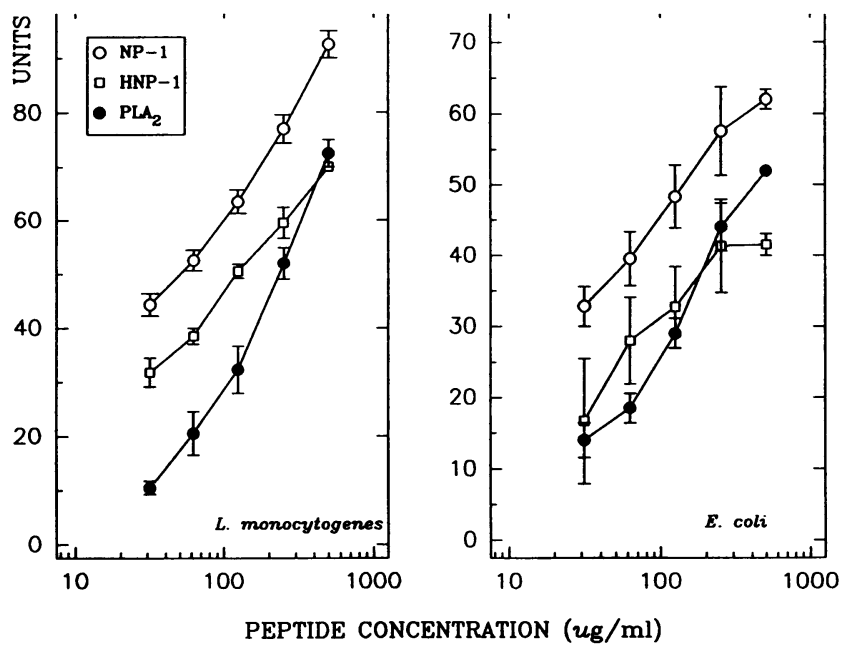

Figure 4. Activity against $L$. monocytogenes and $E$. coli. The bactericidal activities of murine $i$ PLA 2 , rabbit defensin NP-1 and human defensin HNP-1 to kill L. monocytogenes, strain EGD and $E$. coli, strain ML$35 p$ were compared in radial diffusion assays. Data show mean \pm SEM values from four independent experiments.

more sensitive $(P<0.001)$. The differential susceptibility of these isogenic $S$. typhimurium strains to $i \mathrm{PLA}_{2}$ was confirmed by colony counting experiments (Fig. 6), as was the bactericidal effect of $i \mathrm{PLA}_{2}$ on $E$. coli (data not shown). Table I also shows results obtained when these Salmonella strains were challenged with human defensin HNP-1 and a rabbit defensin (NP-2) which is identical in 32 of its 33 residues to NP-1.

The ability of $i \mathrm{PLA}_{2}$ to kill $L$. monocytogenes shown in Figs. 4 and 7 was confirmed by colony count experiments, which showed that concentrations of $12.5 \mu \mathrm{g} / \mathrm{ml}$ or greater sterilized the culture within $60 \mathrm{~min}$ (Fig. $8 a$ ) and that the listericidal effect occurred quite rapidly (Fig. $8 b$ ). Fig. 7 also shows that $i \mathrm{PLA}_{2}$-mediated listericidal activity was highly calcium-dependent. Addition of calcium considerably enhanced the listericidal activity of $i$ PLA $_{2}$, whereas addition of EGTA, a calcium chelator, greatly diminished it. In contrast, magnesium addition did not enhance listericidal activity (data not shown). Fig. 7 also shows that calcium concentrations had little effect

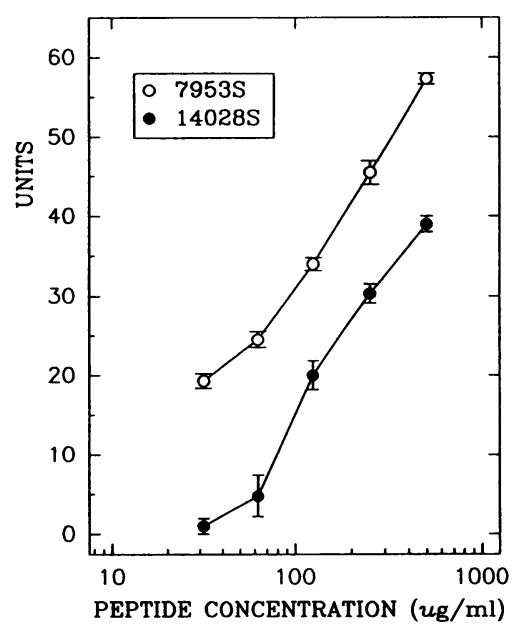

Figure 5. Activity against $S$. typhimurium. Mouse iPLA2 was tested against isogenic $S$. typhimurium strains. Strain $14028 \mathrm{~S}$ (wild-type) is mouse-virulent and Strain 7953S, its isogenic phoP mutant, is avirulent $(54,55)$.
Iable I. Kelative Potency of Defensins and iPLA

\begin{tabular}{llccr}
\hline \multicolumn{1}{c}{ Test organism } & \multicolumn{1}{c}{ Strain } & \multicolumn{1}{c}{$i \mathrm{PLA} 2$} & $\mathrm{NP1} / \mathrm{NP2}{ }^{*}$ & \multicolumn{1}{c}{ HNP-1 } \\
\hline & & $\mu g / m l$ & $\mu g / m l$ & $\mu g / m l$ \\
L. monocytogenes & EGD & $18.8 \pm 2.4$ & $2.6 \pm 0.6$ & $4.9 \pm 0.9$ \\
E. coli & ML-35p & $18.9 \pm 2.6$ & $4.1 \pm 0.4$ & $12.9 \pm 6.1$ \\
$S$. typhimurium & $14028 \mathrm{~S}$ & $43.9 \pm 4.5$ & $14.2 \pm 1.9 *$ & $62.7 \pm 7.1$ \\
$S$. typhimurium & $7953 \mathrm{~S}$ & $12.7 \pm 0.5$ & $5.6 \pm 1.0^{*}$ & $4.1 \pm 0.5$
\end{tabular}

Estimated minimal bactericidal concentrations were estimated from radial diffusion assays and are shown as means \pm SEM. In some experiments (*) rabbit defensin NP-2 was used instead of NP-1. 4-6 individual experiments were performed in the absence of added calcium with each bacterium/peptide combination. Rabbit and human defensins were purified from leukocytes as previously described (61).

on the listericidal activity of defensins. Consonant with these indications that enzymatic activity is required for $i \mathrm{PLA}_{2}$-mediated bactericidal activity, we also found that reduced and alkylated $i \mathrm{PLA}_{2}$, which was enzymatically inactive, failed to kill $E$. coli ML-35 or L. monocytogenes (data not shown).

Although phospholipase $A_{2}$ activity appeared to be necessary for $i \mathrm{PLA}_{2}$-mediated bactericidal activity, enzymatic activity alone was not sufficient, since bee venom $\mathrm{PLA}_{2}$ was much less effective than $i \mathrm{PLA}_{2}$ against $L$. monocytogenes, (Fig. 9) even though it was much more potent than $i \mathrm{PLA}_{2}$ in releasing $\left[{ }^{14} \mathrm{C}\right]-$ oleic acid from radiolabeled autoclaved $E$. coli in our enzymatic assays (Fig. 2).

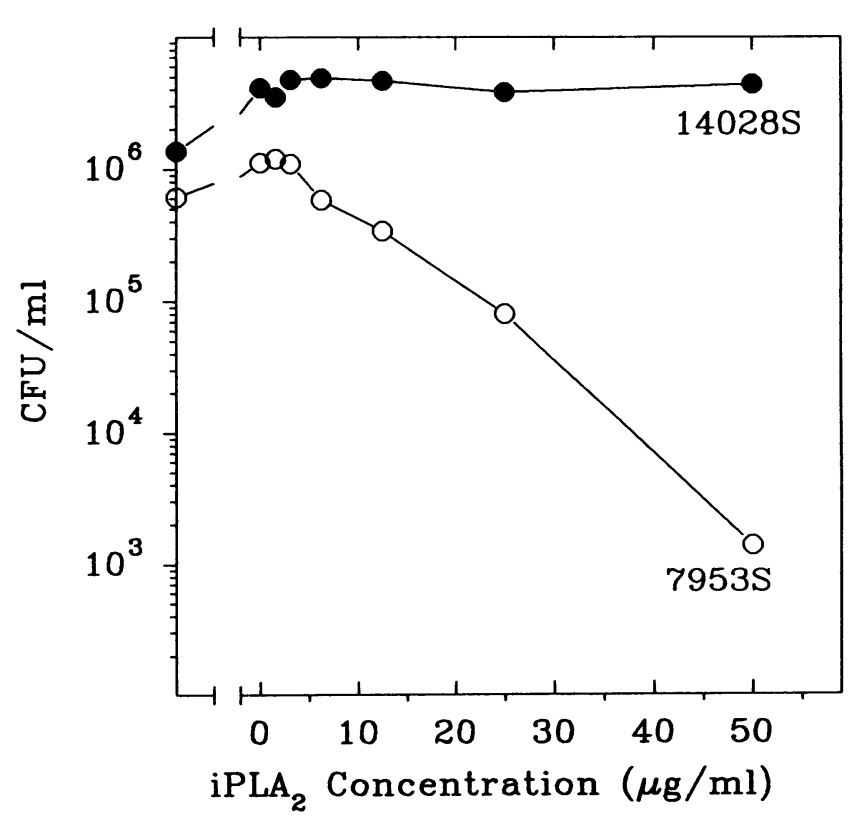

Figure 6. Activity against $S$. typhimurium. Mid-logarithmic phase $S$. typhimurium $14028 \mathrm{~S}$ and $7953 \mathrm{~S}$ were incubated for $60 \mathrm{~min}$ at $37^{\circ} \mathrm{C}$ with the indicated concentrations of $i \mathrm{PLA}_{2}$. The incubations were performed in a dilute trypticase soy broth medium containing $10 \mathrm{mM}$ sodium phosphate buffer, $\mathrm{pH} 7.4$, and $0.30 \mathrm{mg} / \mathrm{ml}$ of trypticase soy broth powder. The input concentrations are shown on the ordinate. 


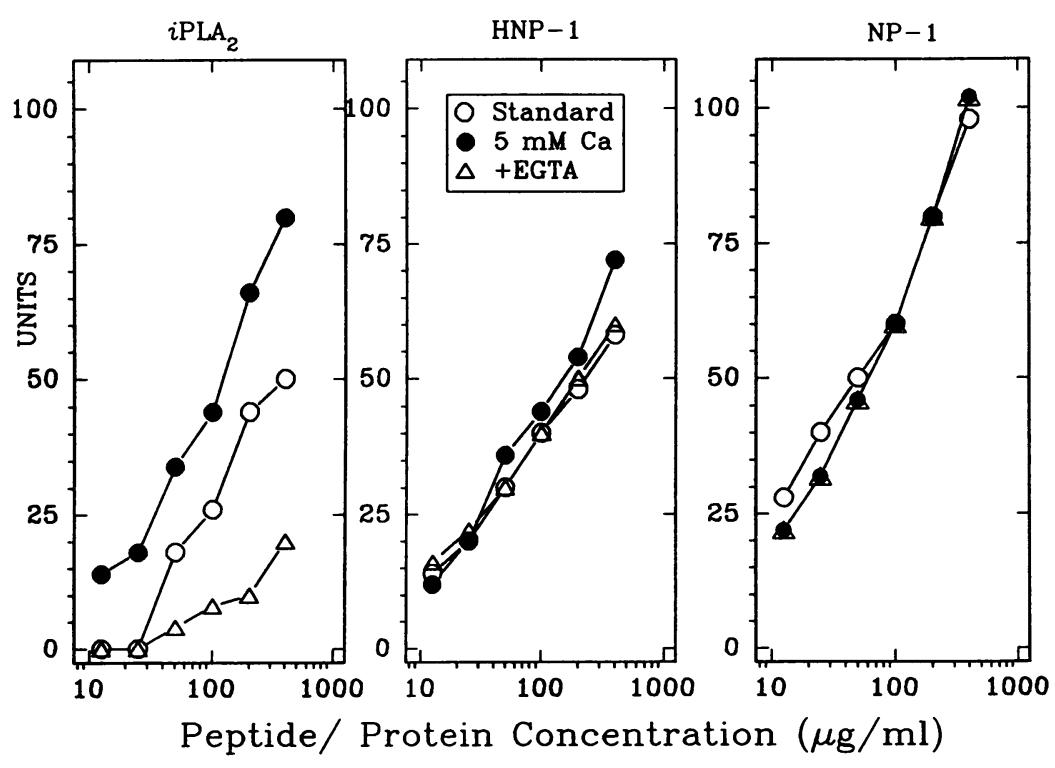

Figure 7. Activity against $L$. monocytogenes. Mouse iPLA2 was tested against $L$. monocytogenes in underlayers that contained $10 \mathrm{mM}$ Hepes without added calcium, $10 \mathrm{mM}$ HEPES $+5 \mathrm{mM}$ calcium or $10 \mathrm{mM}$ Hepes $+1.25 \mathrm{mM}$ EGTA. Also tested under these conditions were human defensin HNP-1 and rabbit defensin NP-1. In this experiment, which was performed with the $>95 \%$ pure $i \mathrm{PLA}_{2}$ preparation, the underlay agarose gel was buffered with $10 \mathrm{mM}$ Hepes, $\mathrm{pH} 7.4$

\section{Discussion}

Type II PLA $\mathrm{P}_{2}$, which is present in the granules of rat and human intestinal Paneth cells $(13,14)$, hydrolyses phosphatidylglycerol, a major bacterial phospholipid, several hundred times more rapidly than phosphatidylcholine, the principal phospholipid of egg yolk (20-22). In a recent report character-

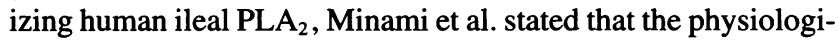
cal role of $i \mathrm{PLA}_{2}$ was unknown, but noted its production by Paneth cells which contained other molecules (lysozyme, IgA, and defensin) that might control the local bacterial milieu (22). The present report provides the first demonstration that $i \mathrm{PLA}_{2}$ is an effective microbicide, whose direct antibacterial potency against $E$. coli, S. typhimurium, and L. monocytogenes approximates that of defensins on a molar basis, even when relatively low concentrations of calcium are present.

All PLA PL $_{2}$ enzymes (E.C. 3.1.1.4) hydrolyze the sn-2 fatty acyl moiety from phospholipids, releasing equimolar amounts of free fatty acids and lysophospholipids. Although these enzymes are often described according to their tissues of origin, as "pancreatic," "splenic," or "intestinal" PLA $_{2}$, it is more useful to classify them according to their structural features and primary sequence. Type I PLA 2 is exemplified by mammalian pancreatic enzymes and homologs found in "old world" elapid snake venoms, whereas the Type II enzymes include intestinal and splenic PLA $_{2} \mathrm{~S}$ and venom constituents of "new world" viperid and crotalid snakes $(23,24)$. The half-cystine residues found at positions 11 and 77 in Type I PLA $\mathrm{A}_{2}$ are transposed to positions 50 and 133 in Type II $\mathrm{PLA}_{2} \mathrm{~s}$, numbered according to Renetseder et al. (25). Type II enzymes also contain a short C-terminal extension, absent in Type I PLA ${ }_{2} \mathrm{~s}$, that ends with a half-cystine residue (23). Although we sequenced only 40 residues of the murine intestinal PLA P $_{2}$, the absence of a half-cystine residue at position 11 , and the protein's size $(\sim 16 \mathrm{kD})$, overall homology to the human and rat intestinal $\mathrm{PLA}_{2}$ (Fig. 3), and enzymatic activity make its identification and classification secure. The primary sequence of murine intestinal PLA2 includes lipophilic residues ( $\mathrm{Ile}^{2}, \mathrm{Phe}^{5}, \mathrm{Ile}^{9}$ ) at characteristic positions of the $\alpha$-helical amino terminal segment which also contains several basic residues, and an intact glycine-rich domain $\left(\mathrm{Tyr}^{25}\right.$ Gly-Cys-X-Cys-Gly-X-Gly-Gly-X-X-X-Pro) that can bind calcium. (26)

Phospholipase $A_{2}$ enzymes are found in all cell membranes, and in the secretory granules (and secretions) of certain cells. The intracellular forms play key roles in phospholipid metabolism (27), membrane remodeling and repair (28), biosynthesis of eicosanoid lipid mediators (29), and G-protein-regulated receptor-mediated signal transduction (30). Extracellular phospholipase $A_{2}$ is present in mammalian pancreatic secretions, snake and arthropod venoms (31), and Paneth cell secretions (see Abstract) and is released by thrombin-stimulated platelets (32). Elevated blood or inflammatory fluid levels of Type 2 $\mathrm{PLA}_{2}$ are found in association with rheumatoid arthritis, septic shock, ulcerative colitis and Crohn's disease, and may contribute prominently to the pathophysiology of these disorders (31, $33,34)$.

The enzyme we call "intestinal" $\mathrm{PLA}_{2}$ in this report has a considerably wider tissue distribution than the Paneth cell. The human "intestinal" and "splenic" Type $2-\mathrm{PLA}_{2}$ are identical $(22,35)$, as are their counterparts in rats $(36)$. Moreover, these "intestinal/splenic" Type $2 \mathrm{PLA}_{2} \mathrm{~s}$ are apparently identical to the enzymes recovered from platelets $(32,37)$, various inflammatory exudates $(26,35,38-40)$ and placenta (41). Consequently, Type $2 \mathrm{PLA}_{2}$ could also mediate non-oxidative antibacterial activity in non-intestinal sites. Although this report deals only with the direct antibacterial effects of intestinal PLA 2 acting in isolation, the enzyme may act in concert with other antimicrobial host molecules, as has been shown with respect to degradation of phospholipids in BPI-treated $E$. coli by Elsbach and associates $(42,43)$.

Recently, Mulherkar et al. $(44,45)$ identified the $20 \mathrm{NH}_{2^{-}}$ terminal residues of "EF"' (enhancing factor), a mouse small intestinal protein that promoted fibroblast growth in the presence of EGF and increased EGF binding to receptor-positive fibroblasts and epidermoid carcinoma cells, as well as to EGFreceptorless NR-6 cells. They reported that EF had phospholipase $A_{2}$ activity (43). As indicated in Fig. 3, the 20-amino terminal residues of $\mathrm{EF}$ are identical to those of the intestinal 

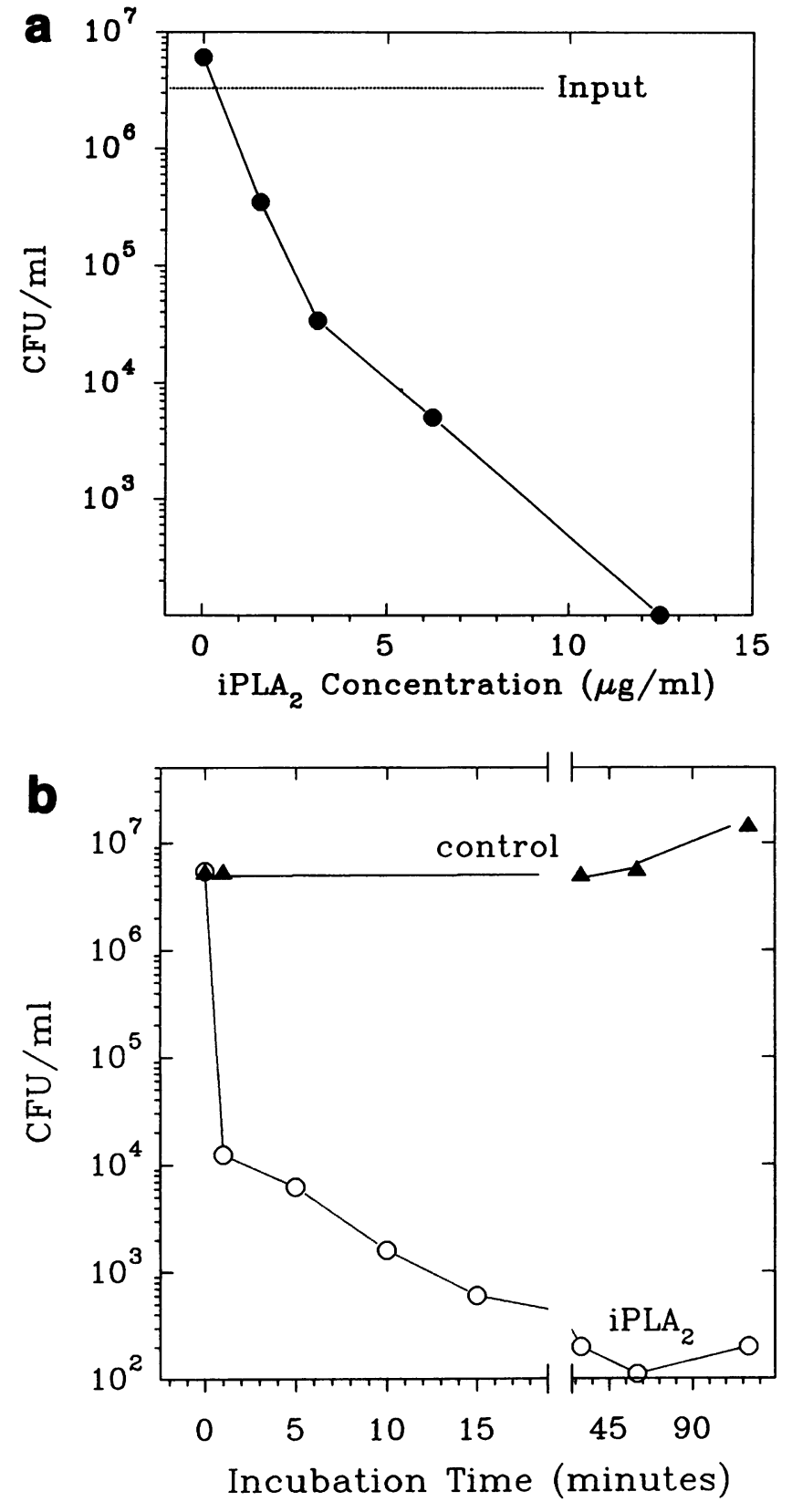

Figure 8. Activity against $L$. monocytogenes. (a). Approximately 3 $\times 10^{6} \mathrm{CFU} / \mathrm{ml}$ of mid logarithmic phase bacteria were incubated for $60 \mathrm{~min}$ at $37^{\circ} \mathrm{C}$ with the indicated concentrations of $\mathrm{PLA}_{2}$ in the medium described in the legend for Fig. 6. (b) Approximately $4 \times 10^{6} \mathrm{CFU} /$ $\mathrm{ml}$ of mid logarithmic phase bacteria were incubated for the indicated times with $12.5 \mu \mathrm{g}$ of $i \mathrm{PLA}_{2}$ or in its absence (control).

phospholipase $A_{2}$ we purified, virtually assuring that they are identical. Thus, Paneth cell-derived $i$ PLA $_{2}$ may not only help to protect intestinal crypts from bacterial incursions, it may also foster the vital processes of epithelial cell renewal that occur within the crypts.

How does Type 2 PLA $_{2}$ kill bacteria? Although we cannot answer the question definitively, a few comments are appropriate. Due to their high ratio of basic $(\mathrm{R}+\mathrm{K}+\mathrm{H})$ to acidic $(D+E)$ amino acids, Type 2 intestinal/splenic $A_{2}$ phospholi-

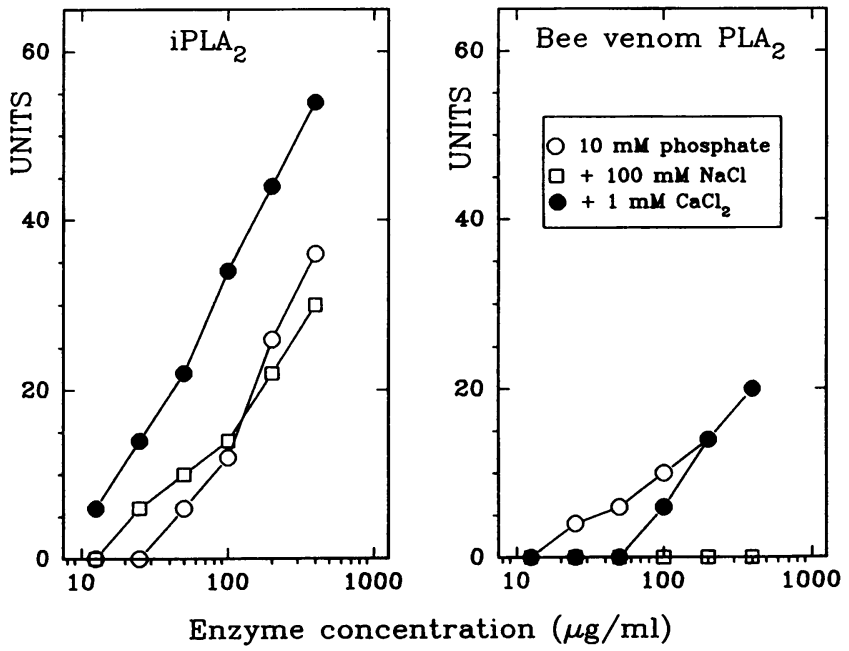

Figure 9. Comparison of $i \mathrm{PLA}_{2}$ and bee venom PLA $\mathrm{P}_{2}$. The murine and bee venom enzymes were tested for bactericidal activity against $L$. monocytogenes in agarose underlay gels buffered with $10 \mathrm{mM}$ sodium phosphate, pH 7.4. Some underlayes also contained $1 \mathrm{mM} \mathrm{CaCl}_{2}$ or 100 $\mathrm{mM} \mathrm{NaCl}$, as indicated in the inset legend.

pases are basic proteins with isoelectric points that exceed 10.5 (32). Their strongly cationic nature favors electrostatic interactions with the (poly) anionic constituents typically found in bacterial cell walls and membranes, and could promote the occurrence of locally high protein concentrations at these vital sites. A correlation between regional (amino terminal) cationicity and the ability to bind to BPI-treated $E$. coli has been shown for various venom enzymes $(46,47)$. Indeed, we have noted that the basic (pI 9.6) isoform of PLA2 from the cobra Naja mocambique mocambique is powerfully microbicidal for S. typhimurium, whereas an acidic isoform of this cobra venom enzyme is nonbactericidal (unpublished data). Although ionic interactions between basic PLA $\mathrm{A}_{2}$ molecules and the bacterial surface should be relatively nonspecific, this process could be further augmented by the unusual affinity of intestinal $\mathrm{PLA}_{2}$ for bacterial phospholipids relative to other phospholipase substrates (Fig. 2 , references 20-22).

Although our data strongly suggest that enzymatic activity is required for the antibacterial effects of Type $2 i \mathrm{PLA}_{2}$, they do not exclude the possibility that $i \mathrm{PLA}_{2}$ also contains domain (s) that could manifest enzyme-independent antibacterial activity, as reported for neutrophil-derived cathepsin $G$ (48) and azurocidin/CAP37 (49). However, $i \mathrm{PLA}_{2}$ is a complexly folded molecule that is stabilized by six intramolecular cystine disulfides and when we reduced murine $i \mathrm{PLA}_{2}$ and alkylated it to prevent spontaneous renaturation, the linearized molecule lost $>99.9 \%$ of its enzymatic activity and $>99 \%$ of its antimicrobial activity. Although this result merely indicates that intact secondary structure is essential for both enzymatic and bactericidal activity, it also mitigates against the likelihood that the molecule can exerts appreciable enzyme-independent antimicrobial activity. Although further delineation of the precise bactericidal mechanism of $i$ PLA $_{2}$ is needed, the use of Paneth cell secretions (50) or tissues other than mouse intestine (e.g., human or animal spleen, platelets or leukocytes) are more likely 
to provide the amounts of Type $2 i \mathrm{PLA}_{2}$ necessary for such studies.

Our finding that the phoP mutant, $S$. typhimurium 7953S, is much more susceptible to $i \mathrm{PLA}_{2}$ than its isogenic parent $S$. typhimurium $14028 \mathrm{~S}$ is especially noteworthy. PhoP is the regulatory component of a bacterial transcriptional activator/ sensory kinase regulon which modulates the production of a cohort of proteins, some of which are virulence-determining (51). PhoP mutants show an impaired ability to survive in murine macrophages $(52,53)$, as well as greater susceptibility to low $\mathrm{pH}(54)$, and to certain antimicrobial peptides $(55,56)$. $S$. typhimurium normally infects its hosts via the gastrointestinal tract, most likely penetrating the intestinal epithelium in Peyer's patches in the distal ileum and then surviving its initial encounters with intestinal macrophages. During this journey, $S$. typhimurium is likely to encounter type II PLA $\mathrm{P}_{2}$ molecules at least twice, first in Paneth cell secretions and next in the lysosomal apparatus of the macrophage. Consequently, phoP-regulated resistance to type II PLA $\mathrm{PL}_{2}$ could ontribute significantly to virulence in this group of enteric pathogens.

\section{Acknowledgments}

We thank Audree Fowler for the microsequencing. This work was supported by grants AI-29595 and AI-29839 from the National Institutes of Health (NIH). The UCLA Protein Microsequencing Facility is supported by a grant, BRS-SIG 1S10RR05554, from the NIH.

\section{References}

1. Gorbach, S. L. 1971. Intestinal Microflora. Gastroenterology. 60:11101129.

2. Ouellette, A. J., and J. C. Lualdi. 1990. A novel gene family coding for cationic, cysteine-rich peptides. Regulation in mouse small intestine and cells of myeloid origin. J. Biol. Chem. 265:9831-9837. A correction appeared in J. Biol. Chem. 269:18,702.

3. Jones, D. E., and C. L. Bevins. 1992. Paneth cells of the human smal intestine express an antimicrobial peptide gene. J. Biol. Chem. 267:23216-23225.

4. Jones, D. E., and C. L. Bevins. 1993. Defensin 6 mRNA in human Paneth cells: implications for antimicrobial peptides in host defense of the human bowel FEBS (Fed. Eur. Biochem. Soc.). 315:187-192.

5. Ouellette, A. J., S. I. Miller, A. H. Henschen, and M. E. Selsted. 1992. Purification and primary structure of murine cryptdin-1, a Paneth cell defensin FEBS (Fed. Eur. Biochem. Soc.). 304:146-148.

6. Eisenhauer, P. B., S. S. L. Harwig, and R. I. Lehrer. 1992. Cryptdins: antimicrobial defensins of the murine small intestine. Infect. Immun. 60:35563565.

7. Selsted, M. E., S. I. Miller, A. H. Henschen, and A. J. Ouellette. 1992. Enteric defensins: antibiotic peptide components of intestinal host defense. J. Cell Biol. 118:929-936.

8. Harwig, S. S. L., P. B. Eisenhauer, N. P. Chen, and R. I. Lehrer. 1995 Cryptdins: endogenous antibiotic peptides of small intestinal Paneth cells. Adv Exp. Med. Biol. In press.

9. Erlandsen, S. L., and D. G. Chase. 1972. Paneth cell function: phagocytosis and intracellular digestion of intestinal micro-organisms. I. Hexamitis muris. J. Ultrastruct. Res. 41:296-318.

10. Erlandsen, S. L., and D. G. Chase. 1972. Paneth cell function: phagocytosis and intracellular digestion of intestinal micro-organisms. II. Spiral micro-organisms. J. Ultrastruct. Res. 41:319-333.

11. Satoh, Y. 1988. Effect of live and heat-killed bacteria on the secretory activity of Paneth cells in germ-free mice. Cell Tissue Res. 251:87-93.

12. Satoh, Y. 1988. Atropine inhibits the degranulation of Paneth cells in experimental germ-free mice. Cell Tissue Res. 253:397-402.

13. Senegas-Balas, F., D. Balas, R. Verger, A. de Caro, C. Figarella, F. Ferrato, P. Lechene, C. Bertrand, and A. Ribet. 1984. Immunohistochemical localization of intestinal phospholipase $A_{2}$ in rat Paneth cells. Histochemistry. 81:581-584.

14. Kiyohara, H., H. Egami, Y. Shibata, K. Murata, S. Ohshima, and M. Ogawa. 1992. Light microscopic immunohistochemical analysis of the distribution of group II phospholipase $\mathrm{A}_{2}$ in human digestive organs. J. Histochem. Cytochem. 40:1659-1664
15. Lehrer, R. I., M. Rosenman, S. S. L. Harwig, R. Jackson, and P. Eisenhauer. 1991. Ultrasensitive assays for endogenous antimicrobial polypeptides. $J$. Immunol. Methods. 137:167-173.

16. Matsudaira, P. 1987. Sequence from picomole quantities of proteins electroblotted onto polyvinylidene difluoride membranes. J. Biol. Chem. 262:1003510038.

17. Harwig, S. S. L., N. P. Chen, A. S. K. Park, and R. I. Lehrer. 1993. Purification of cysteine-rich bioactive peptides from leukocytes by continuous acid-urea- polyacrylamide gel electrophoresis. Anal. Biochem. 208:382-386.

18. Elsbach, P., and J. Weiss. 1991. Utilization of labeled Escherichia coli as phospholipase substrate. Methods Enzymol. 197:24-31.

19. Habermann, E., and K. I. Hardt. 1972. A sensitive and specific plate test for the quantitation of phospholipases. Methods Enzymol. 50:163-173.

20. Mansbach, C. M., G. Pieroni, and R. Verger. 1982. Intestinal phospholipase, a novel enzyme. J. Clin. Invest. 69:368-376.

21. Verger R., F. Ferrato, C. M. Mansbach, and G. Pieroni. 1982. Novel intestinal phospholipase A2: Purification and some molecular characteristics. Biochemistry. 21:6883-6889.

22. Minami T., H. Tojo, Y. Shinomura, Y. Matsuzawa, and M. Okamoto 1993. Purification and characterization of a phospholipase A2 from human ilea mucosa. Biochim. Biophys. Acta. 1170:125-130.

23. Heinrikson, R. L., E. T. Krueger, and P. S. Keim. 1977. Amino acid sequence of phospholipase $A_{2}-\alpha$ from the venom of Crotalus adamanteus. J. Biol. Chem. 252:4913-4921.

24. Johnson L. K., S. Frank, P. Vades, W. Pruzanski, A. J. Lusis, and J. J. Seilhamer. 1990. Localization and evolution of two human phospholipase A2 genes and two related genetic elements. Adv. Exp. Biol. Med. 275:17-34.

25. Renetseder R., S. Brunie, B. W. Dijkstra, J. Drenth, and P. B. Sigler. 1985. A comparison of the crystal structures of phospholipase A2 from bovine pancreas and Crotalus atrox venom. J. Biol. Chem. 21:11627-11634.

26. Seilhamer J. J., W. Pruzanski, P. Vadas, S. Plant, J. A. Miller, J. Kloss, and L. K. Johnson. 1989. Cloning and recombinant expression of phospholipase $\mathrm{A}_{2}$ in rheumatoid arthritic synovial fluid. J. Biol. Chem. 264:5335-5338.

27. Van den Bosch, H. 1980. Intracellular phospholipase A. Biochim. Biophys. Acta. 604:191-198.

28. Glaser, K. B., D. Mobilio, J. Y. Chang, and N. Senko. 1993. Phospholipase $\mathrm{A}_{2}$ enzymes: regulation and inhibition. TIPS (Trends Pharmacol. Sci.). 14:9298 .

29. Chang, J., J. H. Musser, and H. McGregor. 1987. Phospholipase $A_{2}$ function and pharmacological regulation. Biochem. Pharmacol. 36:2429-2436.

30. Axelrod, J., R. M. Burch, and C. L. Jelsema. 1988. Receptor-mediated activation of phospholipase $A_{2}$ via GTP-binding proteins: arachidonic acid and its metabolites as second messengers. TINS (Trends Neurosci.). 11:117-123.

31. Vadas, P., and W. Pruzanski. 1986. Role of secretory phospholipase A in the pathobiology of disease. Lab. Invest. 55:391-404.

32. Kramer, R. M., C. Hession, B. Johansen, G. Hayes, P. Mcgray, E. P. Chow, R. Tizard, and R. B. Pepinsky. 1989. Structure and properties of human non-pancreatic phospholipase $\mathrm{A}_{2}$. J. Biol. Chem. 264:5768-5775.

33. Pruzanski, W., and P. Vadas. 1988. Secretory synovial fluid phospholipase $\mathrm{A}_{2}$ and its role in the pathogenesis of inflammation in arthritis. J. Rheumatol. 15:1601-1603.

34. Minami, T., H. Tojo, Y. Shinomura, T. Komatsubara, Y. Matsuzawa, and M. Okamoto. 1993. Elevation of phospholipase $A_{2}$ protein in sera of patients with Crohn's disease and ulcerative colitis. Am. J. Gastroenterol. 88:1076-1080.

35. Kanda A., T. Ono, N. Yoshida, H. Tojo, and M. Okamoto. 1989. The primary structure of a membrane-associated phospholipase $A_{2}$ from human spleen. Biochem. Biophys. Res. Commun. 163:42-48.

36. Ono T., H. Tojo, S. Kuramitsu, H. Kagamiyama, and M. Okamoto. 1988 Purification and characterization of - mbrane-associated phospholipase $A_{2}$ from rat spleen. Its comparison with - ytusolic phospholipase $\mathrm{A}_{2} \mathrm{~S}-1$. J. Biol. Chem. 263:5732-5738.

37. Chang H. W., I. Kudo, M. Toomita, and K. Inoue. 1987. Purification and characterization of extracellular phospholipase $\mathrm{A}_{2}$ from peritoneal cells of caseinate treated rat. J. Biochem. (Tokyo). 102:147-154.

38. Kramer, R. M., C. Hession, B. Johansen, G. Hayes, P. McGray, E. P Chow, R. Tizard, and R. B. Pepinsky. 1989. Structure and properties of a human non-pancreatic phospholipase $\mathrm{A}_{2}$. J. Biol. Chem. 264:5768-5775.

39. Hara S., I. Kudo, K. Matsta, T. Miyamoto, and K. Inoue. 1988. Amino acid composition and $\mathrm{NH}_{2}$-terminal amino acid sequence of human phospholipase $\mathrm{A}_{2}$ purified from rheumatoid synovial fluid. J. Biochem. (Tokyo). 104:326-328.

40. Hayakawa M., K. Horigome, I. Kudo, M. Tomita, S. Nojima, and K Inoue. 1987. Amino acid composition and $\mathrm{NH}_{2}$-terminal amino acid sequence of rat platelet secretory phospholipase $\mathrm{A}_{2}$. J. Biochem. (Tokyo). 101:1311-1314.

41. Lai C.-Y., and K. Wada. 1988. Phospholipase $A_{2}$ from human synovial fluid: purification and structural homology to placental enzyme. Biochem. Biophys. Res. Commun. 157:488-493.

42. Wright, G. W., C. E. Ooi, J. Weiss, and P. Elsbach. 1990. Purification of a cellular (granulocyte) and an extracellular (serum) phospholipase $A_{2}$ that 
participate in destruction of Escherichia coli in a rabbit inflammatory exudate. $J$. Biol. Chem. 265:6675-6681.

43. Weiss J., G. Wright, A. C. A. P. A. Bekkers, C. J. van den Bergh, and H. M. Verheij. 1991. Conversion of the pig pancreas phospholipase $A_{2}$ by protein engineering into enzyme active against Escherichia coli treated with the bactericidal/permeability-increasing protein. J. Biol. Chem. 266:4162-4167.

44. Mulherkar, R., R. Rao, L. Rao, V. Patki, V. S. Chauhan, and M. G. Deo. 1993. Enhancing factor protein from mouse small intestines belongs to the phospholipase $A_{2}$ family. FEBS (Fed. Eur. Biochem. Soc.). 317:263-266.

45. Mulherkar, R., and M. G. Deo. 1986. Further studies on the enhancing factor and its possible mechanism of action. J. Cell. Physiol. 127:183-188.

46. Forst, S., J. Weiss, J. M. Marangore, R. L. Henrikson, and P. Elsbach. 1987. Relation between the binding and the action of phospholipases A2 on Escherichia coli exposed to the bactericidal/permeability-increasing protein of neutrophils. Biochim. Biophys. Acta. 920:221-225.

47. Forst S., J. Weiss, P. Elsbach, J. M. Maraganore, I. Reardon, and R. L. Heinrikson. 1986. Structural and functional properties of a phospholipase $A_{2}$ purified from and inflammatory exudate. Biochemistry. 25:8381-8385.

48. Bangalore, N., J. Travis, V. C. Ohnunka, J. Pohl, and W. M. Shafer. 1990. Identification of the antimicrobial domains in human neutrophil cathepsin G. $J$. Biol. Chem. 265:13,584-13,588.

49. Pereira H. A., I. Erdem, J. Pohl, and J. K. Spitznagel. 1993. Synthetic bactericidal peptide based on CAP37: a $37 \mathrm{kDa}$ human neutrophil granule-associated cationic antimicrobial protein chemotactic for monocytes. Proc. Nat. Acad. Sci. USA. 90:4733-4737.

50. Qu, X-D., S. S. L. Harwig, L. Tan, K. C. K. Lloyd, J. H. Walsh, and R. I. Lehrer. 1994. Neural control of endogenous antimicrobial peptides from small intestinal Paneth cells: an unexpected nexus between the nervous and immune systems. FASEB (Fed. Am. Soc. Exp. Biol.) J. 8LA248 (Abstr.)

51. Miller, S. I., A. M. Kukral, and J. J. Mekalanos. 1989. A two-componen regulatory system (phoP/phoQ) controls Salmonella typhimurium virulence. Proc. Natl. Acad. Sci. USA. 86:5054-5058.
52. Fields, P. I., R. V. Swanson, C. G. Haidaris, and F. Heffron. 1986. Mutants of Salmonella typhimurium that cannot survive within the macrophage are avirulent. Proc. Nat. Acad. Sci. USA. 83:5189-5193.

53. Buchmeier, N. A., and F. Heffron. 1989. Intracellular survival of wildtype and macrophage-sensitive mutants in diverse populations of macrophages Infect. Immun. 60:571-577.

54. Foster, J. W., and H. K. Hall. 1990. Adaptive acidification tolerance response of Salmonella typhimurium. J. Baceriol. 172:771-778.

55. Groisman, E. A., C. Parra-Lopez, M. Salced, C. J. Lipps, and F. Heffron 1992. Resistance to host antimicrobial peptides is necessary for Salmonella virulence. Proc. Natl. Acad. Sci. USA. 89:11,939-11943.

56. Miller, S. I., W. S. Pulkkinen, M. E. Selsted, and J. J. Mekalanos. 1990 Characterization of defensin resistance phenotypes associated with mutations in the phoP virulence regulon of Salmonella typhimurium. Infect. Immun. 58:37063710.

57. Forst, S. J. Weiss, P. Blackburn, B. Frangione, F. Goni, and P. Elsbach. 1986. Amino acid sequence of a basic Agkistrodon phospholipase A2. Possible role of $\mathrm{NH}_{2}$-terminal lysines in action on phospholipids of Escherichia coli. Biochemistry. 25:4309-4314.

58. Verheij, H. M., J. Westerman, B. Sternby, and G. De Haas. 1983. The complete primary sequence of phospholipase A2 from human pancreas. Biochim. Biophys. Acta. 747:93-99.

59. Seilhamer, J. J., T. L. Randall, M. Yamanaka, and L. K. Johnson. 1986 Pancreatic phospholipase $A_{2}$ : Isolation of the human gene and cDNAs from porcine pancreas and human lung. DNA. 5:519-527.

60. Puijk, W. C., H. M. Verheij, and G. M. DeHaas. 1977. The primary structure of phospholipase $A_{2}$ from porcine pancreas: a reinvestigation. Biochim. Biophys. Acta. 492:254-259.

61. Harwig, S. S. L., T. Ganz, and R. I. Lehrer. 1994. Neutrophil defensins: Purification, characterization and antimicrobial testing. Methods. Enzymol. 236:163-172. 